\title{
Symbolic Interaction of Director of Photography in Film Production Organizing at Camera Department
}

\author{
Citra Dewi Utami ${ }^{1, \text { a) }}$ Budi Dwi Arifianto ${ }^{2)}$ \\ ${ }^{1}$ ISI Surakarta \\ a) author correspondence: citra_de@isi-ska.ac.id \\ ${ }^{2}$ Universitas Muhammadiyah Yogyakarta
}

.. DOl: https://doi.org/10.18196/jkm.112029

Article Info

Article history:

Received 26 Oct 2019

Revised 31 Oct 2019

Accepted 13 Nov 2019

\begin{abstract}
Film production is a collaborative work process that involves many workers. Proper management is needed to achieve effective and efficient production results. Organizing is the second function of management work. The film production workers are divided into several departments, one of which is the camera department. In this department, all visual matters are accounted for. Director of Photography (DP) is the leader. Data collection in this research was carried out through archive studies, observations, and interviews. This article discusses how DP symbolically interacted in certain pattern with directors, producers, and crew in the camera department. The discussion uses the five concepts of Blumer's symbolic interaction, namely self-concept, the concept of action; object concept; the concept of social interaction; and the concept of joint action. The results of the discussion from this study indicate that the DP interacts with the director through productive self-appearances, has improved visual aesthetic achievements, and masters the latest equipment through works uploaded on social media. The action shown by the DP to the director as the boss is communicated using the concept language and his efforts to the camera department crew as subordinates are communicated using technical language. The DP interacts with the producer through a work contract; The DP interacts socially symbolically with the broader community through language selection that is adapted to the working environment. Finally, the DP interacts through collective action, working together with one department worker and between departments in a production process so that they can work together to produce a film.
\end{abstract}

Keywords: Director of Photography (DP); film production; organizing; work; symbolic interaction.

\begin{abstract}
ABSTRAK
Produksi film adalah proses kerja kolaboratif yang melibatkan banyak pekerja. Manajemen yang baik dibutuhkan guna mencapai hasil produksi yang efektif dan efesien. Pengorganisasian merupakan fungsi kedua dari sebuah kerja manajemen. Para pekerja produksi film terbagi menjadi beberapa departemen, salah satunya adalah departemen kamera. Pada departemen tersebut segala urusan visual dipertanggungjawabkan. Director of Photography (DP) merupakan pimpinannya. Pengumpulan data dalam penelitian ini dilakukan melalui studi arsip, observasi dan wawancara. Artikel ini membahas tentang bagaimana DP secara simbolik berinteraksi melalui pola tertentu dengan sutradara, produser serta para kru dalam departemen kamera. Pembahasan menggunakan lima konsep interaksi simbolik Blumer yaitu konsep diri;
\end{abstract}




\begin{abstract}
konsep aksi; konsep obyek; konsep interaksi sosial; dan konsep tindakan bersama. Hasil pembahasan dari penelitian ini menunjukkan bahwa DP berinteraksi dengan sutradara melalui penampilan diri yang produktif, memiliki capaian estetika visual yang terus meningkat, dan menguasai peralatan terkini melalui karya yang diunggah pada media sosial; aksi yang diperlihatkan DP kepada sutradara selaku atasan dikomunikasikan menggunakan bahasa konsep dan aksinya kepada kru departemen kamera selaku bawahan dikomunikasikan menggunakan bahasa teknis; DP berinteraksi dengan produser melalui kontrak kerja; DP berinteraksi sosial secara simbolik dengan masyarakat luas melalui pemilihan bahasa yang disesuaikan dengan lingkungan pergaulan kerjanya; dan DP berinteraksi melalui aksi kolektif, bekerja sama dengan pekerja satu departemen dan antar departemen dalam suatu proses produksi sehingga dapat bersinergi menghasilkan sebuah film.
\end{abstract}

Kata Kunci: Director of Photography, interaksi simbolik, kerja, pengorganisasian, produksi film.

\section{INTRODUCTION}

Development in the Indonesian movies industry is in line with infrastructure, regulation, and crew improvement. Discussion about the competency standard of film crews is in the process of perfection, and the makers hope to attain a certain measurable standard. Nevertheless, film production is a realm that is replete with adjustment. Real condition in the field is typically different from what has been planned, how well it is. The crews, then, are supposed to interact effectively to get the hang of the uncertainty.

Organizing is the second function of management. In general, it aims to arrange organizational structure according to the organization's objectives, sources, and environments, and, in particular, for human resource division, for deciding the tasks and authorities of each member, including the specialization. Standardization, coordination, measurement of each workgroup, and issues related to centralization or decentralization in the deciding making process are some of the other examples. The purpose of management is to realize productive and efficient results and the strategies designed to procure the targets. Each member of management should own strategies to reach the goal well. Although the work system is deemed new and not systematized yet, considering the fluidity, work organizing in the movie industry is considerably adaptive (Grugulis and Stayonova, 2009, 137).

The problem is the learning process, regeneration, and competency increment of the workers. Typically the learning process in the industry occurs while working, but rapid technological changes in the film industry engender the workers always to renovate their knowledge and abilities. Workers, as a part of the work structure, coupled with specialized skills and targets of a specific goal, are the co-entangled triangle of work organizing. The more systematic the description of the work system, the more comfortable they improve the worker competency. Eventually, it might contribute to productivity increment. The government regulates workers in the creative industry through Film Act No. 33, 2009, Clause 20. It says 13 film crews work in the film industry, and they consist of scriptwriter, director, actress, cameraman, lighting, sound designer, voice editor, music editor, stylist, choreographer, image editor, producer, and animation. In practice, the number of positions that are involved can reach seven times bigger. Camerapeople are one of many that are written and the representation of the camera department.

Director of photography (DP) is the leader of the camera department that shoulder visual aspects of film production, and the camera department itself is a group of film crews that are responsible for the creative process. DP is accountable to the director, as the creative leader as a whole, and consults with producers as the production leader. In the camera department, DP is mainly assisted by the gaffer and key grip, not to mention camera operator, 1st assistant camera, 2nd assistant camera, digital imaging technician, best boy lighting, best boy grip, and other supporting crews. Tasks, responsibilities, and interactions among the team are explained in the work organization. Admittedly, since the power of language and visual aesthetic in a film play a 
significant role in delivering a message to the audiences, the communication process run is quite complicated and includes from composition arrangement relating to the placing of camera level, the framing of the picture size, and the motion. It is the reason for which the involvement of each crew in the camera department in film production with effective work organizing is essential to attain optimal results.

This research will focus on symbolic interaction among DP, producer, director, and department camera crew. In addition, the research investigates work organizing, strategy to reach the target, and the solution picked to deal with the issues. Furthermore, as Chapman said that "the industrial nature of film production, and the input of a range of creative agencies during the film-making process are essential part of the New Film History" (Chapman, 2007,69), the other main motive that found the research is to describe the process of film production coming from perspective that is non-director, which are frequently have been discussed.

Indonesia is culturally unique, and it affects, directly and indirectly, the way films are produced. For example, Imanda contended that "dwellers of Tutup Ngisor village actively explore suitable methods to make a film for themselves" (Imanda, 2018, 87). It shows that the process of film production is open to adjustment in the work organizing. Although, on the one hand, it can be a sign of the immaturity of the Indonesian system of film production; on the other hand, it also can be an indication of the determination of cultural value in the way film is made. For that reason, the research will describe the work organizing of film production that runs in two different locations in Indonesia.

Film production consists of five stages, namely development, pre-production, production, postproduction, and distribution (Rea, 2010: xxii-xxiii), and DP, in the process, starting from pre to post-production, requires practical conceptual and technical skills. It is because the film as a media communication construct and display various messages using signs, and it is interpreted as communication media. However, symbols appearing from the workers could also be understood as communication in the form of symbolic interaction. It is vital to understand how symbolic interaction occurs in this case among workers, whether in the same department or inter-department since interpretation emerges from that symbol exchange process.

\section{METHOD}

The research used a qualitative approach in describing social symptoms happening in the film industry, and the data in this research was collected using documentation techniques by taking pictures uploaded on the informants' social media in the last three years, production observation, and interviews. Informants were selected based on their locations, namely Yogyakarta and Bali. Those two locations were chosen because of the differences in the work environment and culture. Finally, the data was analyzed and displayed descriptively and qualitatively to draw a conclusion of symbolic interaction that occurs in the process of film production, notably in the camera department in which DP was the primary subject matter.

The data collection was conducted with documentation, observation towards the subjects, and indirect interviews. In addition to the condition in the film production process as an uncertain situation, a film worker is a creative and innovative self that is ready to improve in a case that is not suitable for the plan. Film production results in social interaction among the workers during the production process, ranging from the development stage to distribution. Communication in the interpersonal level that prioritizes face-to-face interaction is named symbolic interaction. This research placed DP and the behaviors in film production as the subject-matter. Despite the researcher's background that is also a filmmaker, informants chosen were DP that had a close relationship with the researcher so that the researcher could understand the real empirical condition.

The data collection obtained through screenshots on social media, namely Instagram, and indirect interviews towards two Indonesian DP who worked professionally in Yogyakarta and Bali, respectively. The first informant is Satria Kurnianto (SK), and the second informant is I Made Denny Chrisna Putra (DC). SK is a DP that grew and processed in Yogyakarta. He studied film production at a film school and participated actively in a film community. SK's background as a DP is related to film communities network in Yogyakarta. His films mostly are resulted from his partnerships with Yogyakarta directors, and it cannot be separated from his process in Yogyakarta. On the other hand, DC is a DP who graduated from film school in Yogyakarta too. He is a master holder in videography and works professionally in Bali. DC's career started from a foreign 
producer's network producing his films. The needs of film workers in Bali based on the demands of foreign producers become the background of DC existence as one of the most productive DP.

The framework of the research was established from an understanding of a symbol as a prefix. A symbol is a social object in human interaction, and it is used as communication media and representation that are determined by the users. The users give meaning and create and transform an object in the interaction. A social symbol might form as entities, words, or actions. An entity is a physical object, words can represent physical objects, feelings, idea, and value, while the action is behavior that put meaning in the communication with other people (Charon, 1979, 35-56).

\section{RESULT AND DISCUSSION}

Discussion regarding symbolic interaction in the research was based on Blumer's five concepts (Blumer in Veeger, 1993:224-227), and those are:

1. Self-concept: DP was seen as a conscious organism that reflected himself and could interact interpersonally.

2. Action-concept: DP was seen as an actor that planed communication in the work process to handle the situation and not be handled by the case. The action was a constructive result and not merely a biological reaction.

3. Object concept: DP was seen as a team member working in the middle of the production process, with the aim that had been determined.

4. Social interaction concept: DP was seen able to shift himself in another position in the interaction to assimilate the action with other team members. Interpretation of others' gestures and movements was conducted actively throughout process production.

5. Joint action concept: DP, coupled with other film crews, did collective action that emerged from each deed, and those were matched up and suited to each other. This concept fused and synergized the aim, thought, and behavior.

Symbolic interaction that will be discussed in this research refers to communication that uses symbols to comprehend the work organizing of DP in the film work production. This symbolic interaction represented the unique nature of the interaction between the camera department leader and other departments, as well as other workers in the same department. In other words, film workers co-interpret and co-define their actions, whether in the interaction with other people or themselves. The interaction formed involved symbols, film production technics, ethic professions, and the views of DP.

Workgroup in film production is a social group consisting of individuals with various skills and abilities to produce a film as the objective. Research on the film crew, as do by this research, is an effort to comprehend the values of each film crew, which work in a particular position, through their own experience. Film production management is understood as basic social processes that are divided into project germination, project creation, and project facilitation (Jones, M.L., 2005, 143-153). Those three processes are entangled and contiguous. The collaboration process happens in the social process. Each stage involves crews that professionally present and act according to their job desks. Those skills are supported by skills to interact symbolically, understand each other, and have work deals among them.

The basic idea of symbolic interaction in this context is that the film crews are a group of humans that interacted with each other, and the director of photography (DP) is one of the members. That interactive activity co-synergize through joint action and creates a social structure. DP interacts through various activities that relate to other workers in film production. DP's symbolic interaction was described and analyzed through an interpretation of the actions. The interpretation is production from symbolic interaction. While objects do not have intrinsic meaning, they could be categorized into three parts, physical, social, and abstract objects. DP does not only recognize external objects but also sees himself as another object.

Actions that are carried out by DP are interpretative action that is made by them. Joint work is also DP's action. All elements are interconnected and matched with the film production. Mostly, collective activities are conducted repeatedly on stable conditions and eventually breed culture. The culture that is born during the production process from worker interaction can be seen as a working culture. It is drawn from the premise that DP acts based on the meaning that is available 
in the production work process. Meaning gained is a result of social interaction carried out by the workers. Those meanings are perfected during the interaction process.

\section{DP's Interaction with Director}

DP, as the camera department leader, has tasks and responsibilities since the stage of development to post-production. In the development stage, DP is posited as the discussion and debate partner of the director. DP is responsible for visual concepts and technical planning imagined by the director. When they are entering the production process, DP acts as the leader of the department that shoulders the tasks to give crews in camera department instructions. Until the post-production process, DP had roles in supervising and maintaining the consistency of the agreed visual concepts realization in each production.
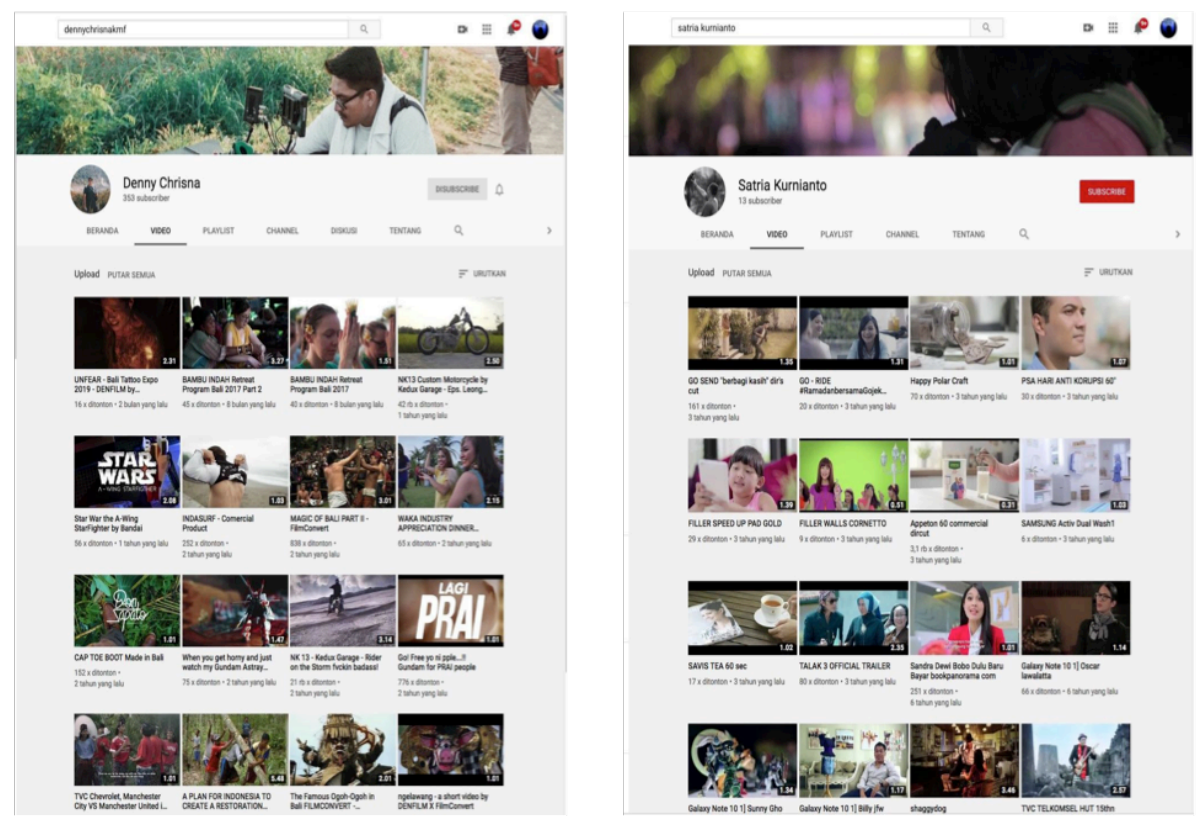

Figure 1. Footprint of Satria Kurnianto's and I made Denny Chrisna's work (Source: Satria Kurnianto's dan Denny Chrisna's Youtube Channel, 2019)

Social media is seen and used by many people, including DP, as a communication tool and to interact symbolically in turn. Pictures uploaded through SK's and DC's Instagram were chosen to interpret their work organizing in film production, especially the camera department. Picture number 1 shows video clips and movie trailers produced by SK and DC, and it is framed with collage style. That arrangement could be seen as an interactive process of DP in delivering his self-concept. The records of works of film workers become essential, considering that film as one sub-sector in the creative industry has multiple characters, that is innovative, risky, uncertain, performing. It is different from a mass-product that demands the actors always to develop themselves. These creative works have created a new working class that lives in the urban area, with their own identity, interest, work structure, work ethic, network, and communication, as opposed to previous workers (McKinlay and Smith, 2009, 12-13). In the past, one's work experience was represented with an official document, but now, that works can be displayed without traditional mediation. DP's interaction was intended to connect with directors, and he delivered as if he said that he is experienced. The director could pick DP that is suited with their expectation to realize their visual image, although the last decision is still in the producer's hand. The interaction that occurred is that the director used the arrangement of DP's work as a material to weight whether the person deserves to take responsibility in his production. The meeting between DP and the director happened in the pre-production meeting. In this stage, the production plan is set up, and the design of the visual concept of shots are created. The self-concept is constructed by DP to show his quality to directors. 
The visual style promoted in DP's arrangement of works can be used as a standard, even discussion, in the next work planning. Also, the track record shows which director that has made partnerships with the DP. The director directed DP through discussion and debate on the visual concept of a script chosen. DP's previous work can be a reference to initiate a new visual concept. A DP is guided to create a visual concept that has philosophical meaning, and the launched idea should have motivation in translating the work. Interaction between DP and director established through conceptual discussion placed DP as a subordinate that is led.

Furthermore, the most vital process is how the skill appears in the interactions that occur because of symbols in the communication process during film production as stated by Maltby, "...technical innovation and craft and of the multiple and interconnected organizational cultures that characterize the film industry” (Maltby, 2011, 9). DP can coordinate and control the visual concepts to manifest in the movie.

DP, after that, endeavored to derive the visual concept to technical artisans that can be understood by the gaffer and key grip. Gaffer is the leader of the lighting team that is responsible for lighting design according to DP's instruction. On the other hand, Key grip is the team leader of a group that responsible for supporting equipment of the camera department, and the equipment is lighting installation, dollies, dolly track, and crane. Technical crafting can be understood as an arrangement of camera and lighting design, as well as selection and organizing equipment and the supporters. Work organization is perceived as a tool to conduct partnerships with other groups of workers to reach the aim. Work organization is an activity that relates to work division, work connection, the delegation of authority, integration, and coordination in the organization (Hasibuan, 2014, 10). Organizing functions in management as an effort to realize the organization effectively.

Similarly, the camera department also experiences that. Work division of DP is divided into two wings, namely as a concept maker and executor. Work system consists of job desks that are accepted through deals and conducted by all crew in the work unit to support work organization (Wil van der Aalst and Hee van Kees, 2004, 15). The crews in the camera department create a working system that is conducted during production time. At that time, they interact symbolically through joint action. Each team fully understands the task and responsibility.

Design is vital in this case since lighting sources could give unique motivation towards shooting sessions, as well as the efficiency and the effects. Crews in the camera department will serve in the form of provision and equipment arrangements needed during the production time as DP's instruction. In this process, DP is posted as the leader of the camera department while providing entertainment facilities to enhance the crew's motivation. Collective works between DP and the teams in the camera department in realizing pictures as visual concepts thought by the director can be seen as a process of symbolic interaction.
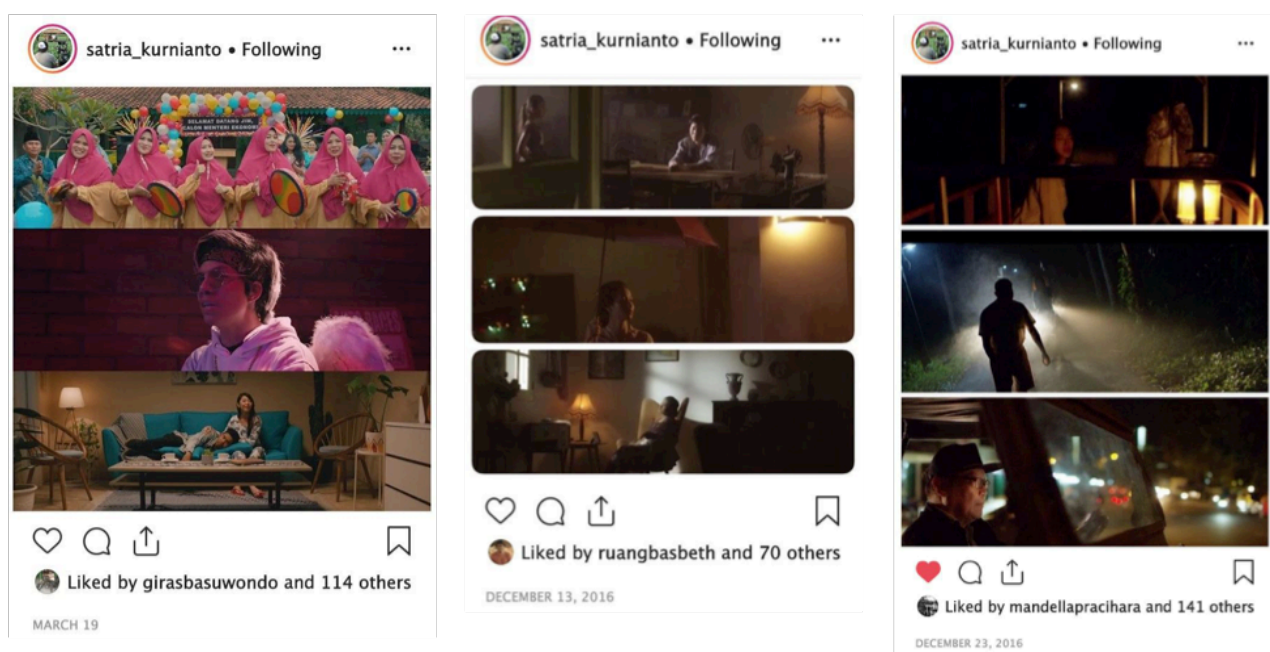

Figure 2. Shot trailers

(Source: Instagram@satria_kurnianto, 2019) 
Picture no. 2 shows some trailers of shots from films made by SK. Picture composition that is displayed is a sign of aesthetic visual achievement of DP. Symbolic interaction happened between DP and director is about the competency in visual form. Aesthetical visual completion of DP can be seen from how highlight, middle highlight, middle light, and shadow of a picture that is suitable with the motivation can be made well. A scene that is composed of several scenes can be dynamic and have an image have deepness. DP is always demanded visually to experiment so that the picture resulted is not monotonous. Through photos that are uploaded, DP tries to communicate the result of that visual experiment. Director considers DP's visual achievement to pick someone responsible for executing his imagination. SK's experience in Yogyakarta makes him be adaptive personality, mostly because the film community in Yogyakarta often involves workers coming from different groups (Dyna H. Dkk, $2015,40)$.

\section{DP's Interaction with Producer}
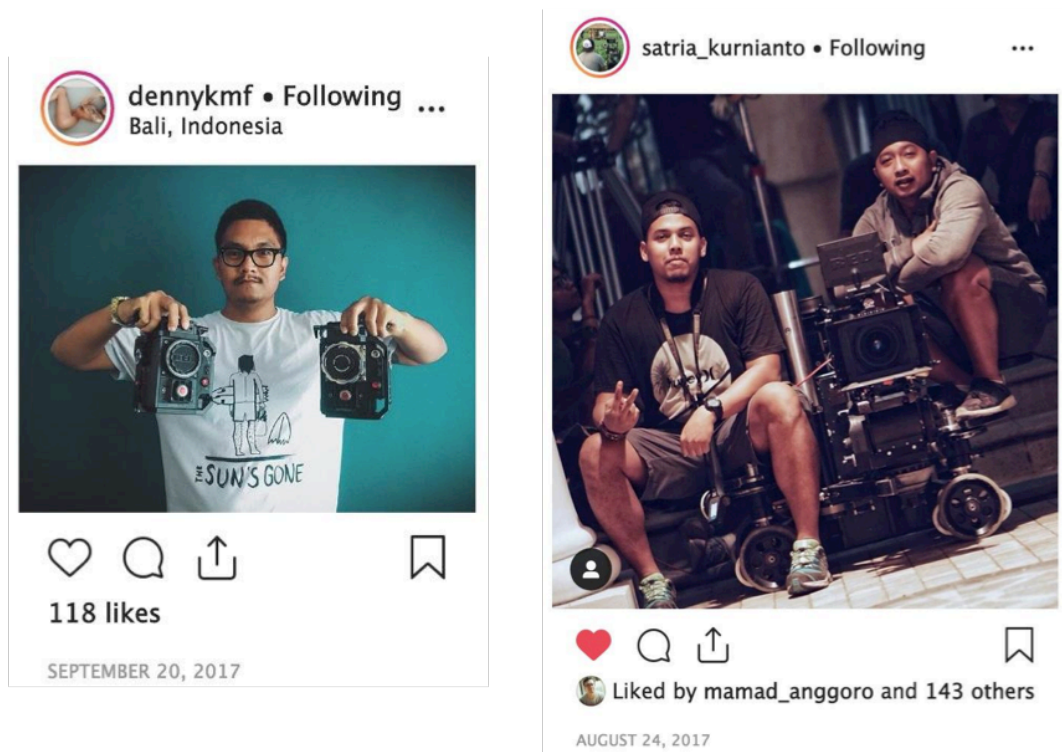

Figure 3. DPs with their film production equipment

(Source: Instagram@satria_kurnianto and @dennykmf, 2019)

Visual recording equipment, or only a camera, is crucial equipment in production. Capable of operating it with the standard operation procedure $(S O P)$ is a skill that should be mastered by a DP. Insight on the advantages and disadvantages of equipment used becomes vital to make a picture in line with the script and the director's imagination. Through taking selfies with the latest series of cameras, DP interacts symbolically with the director, producer, society, and also producer of film production equipment. It can be interpreted as a symbol that he could operate the most current facility to realize the director's imagination on a script. It is, therefore, also a symbol for the producer that the DP could use the latest camera. It is a sign that the DP is the type of person that always tries to improve the quality so that deserving higher pay. Through review toward the latest camera he writes, DP interacts symbolically with the society and camera producers. For society, it implies that he is an expert that can be a reference, and, for the factory, the DP is a person that is representative to be the brand ambassador of the product.

DP does not only interact with crews in one department but also with other departments, which one of them is the production department. In this case, symbolic interactions that happen can be seen through the employment contracts that contain the schedule and the amount of remuneration. When a DP signs the employment contract, the program created by the producer, as the one who is responsible for the schedule, is accepted. With DP self-value, the producer is asked to interpret the class of the DP symbolically to consider the amount of pay the DP will earn and the facilities will have during the production. Class here is defined as the rank of DP based on experience and professionalism. The longer the experience of the DP produces quality films, the higher the pay will be earned. 
A camera with a brand RED that was reviewed by DC is a video camera with sophisticated specifications that is capable of bridging professional and independent needs. The current technological sensor makes the camera with this wide dynamic range is able to create smooth beauty in detail through a low key lighting concept, which is never be tried before. Furthermore, RED offers a resolution that can be used for the big screen, as well as be modified with special effects in the postproduction stage. This camera, whether the hardware or the software, is designed to be modified like a customized computer. The image recorder figures significantly in the visual achievements of a movie. Skill in operating and use the facility is a must that should be mastered by a DP. Digital equipment that is replete with flexibility, compared to the analog, requires the users to understand the new workflow.

\section{DP's Interaction with the Work Environment and Society}
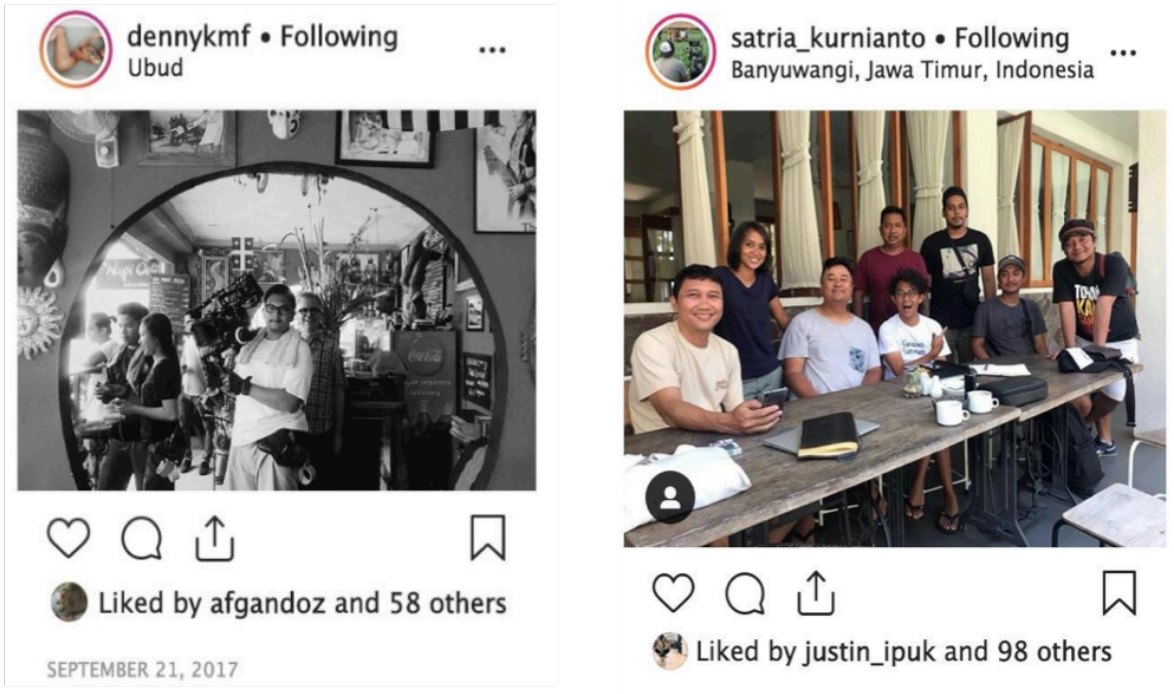

Figure 4. $D P$ with the Film Production Teams

(Source: Instagram@satria_kurnianto dan@dennykmf, 2019)

DC uploaded pictures when producing movies with expatriates. It can be seen as symbolic interaction, meaning that he works in the international environment and creates works for international consumption. English caption to explain the pictures strengthened symbolic interaction that is established between DC and broader society. DC's circumstances that involved many foreign investors contributed to his working culture. Balinese film crews have different work cultures from other film crews in other regions. As stated by Caldwell "Film/television production communities themselves are cultural expression and entities involving all of the symbols processes and collective practices that other use: to gain and reinforce identity, to forge consensus and order, to perpetuate themselves and their interest, and to interpret the media as audience members"(Caldwell, 2008,2). It is in line with the researcher's argument that each film worker triggers the working culture itself. Observation during working is made to understand symbolic interaction patterns. A statement also justifies that culture affects work organizing, notably in the creative industry (Smith and McKenlay, 2009, 12).

Bali is a place that is chosen as shooting locations for film production because of the abundance of scenic spots, ranging from beaches, mountains to vast rice fields. Balinese culture that is mostly conserved in the wave of modernity gives people commonplace activities its distinctive feature. The architecture and residents' planning can be recognized easily because of uniqueness. The reasons make many film producers from other countries choose Bali as the setting of their movies. Furthermore, since Jakarta as the center of the industry and the workers are reasonably far from Bali, meaning higher cost should be spent, many investors directly come to Bali without transiting in Jakarta. It is an efficient and effective method to choose from. When a producer has brought all his 
crews in Bali, another strategy to cut the budget of production cost is still needed; one of them is by employing a local team. However, film crews in Bali are limited. This situation is an opportunity for professional film crews to work in Bali. This condition is understood by DC and triggered him to start his professional career in Bali after finishing his film education in Yogyakarta.

\section{CONCLUSION}

A production film team is a social group that consists of workers. A work organizing in a film production involves many crews that greatly figure in production management. Effective communication among them is required, and one of them is symbolic interaction. The capability of recognizing the symbols is the sign of the success of the communication process that happens. Message delivery from communicator to communicant via symbols calls for interpretation from each side. The production processes are started from the developmental stage, and the workers undergo all of the steps. The job desk and responsibility have been decided.

DP, as someone responsible for picture creation, interacts with many camps, and the director, producers, society, and crews in the camera department, are some examples of them. Rarely does a study place non-director as the subject-matter, and this research is an effort to enrich understanding of new film history in Indonesia. The research has found that DP interacts with the director in terms of productivity, visual aesthetic achievement, and current equipment. The selfvalue of DP can be seen from their previous movies. DP interacts with the director as the leader through conceptual language and communicates with crews in the camera department as the subordinate through technical language. DP interacts with the producer through employment contact and socially interacts with the symbol with broader society through the language used in explaining the works. Finally, DP interacts through collective action by partnering with the workers from one department and another in a production process that leads to synergy to produce a film.

One of the keys to successful film production is the optimization of organizing the workers. Effective interaction is an indicator of effective communication. Each crew could complete the job and responsibility effectively and efficiently.

\section{REFERENCES}

Aalst, Wil van der and Kees, van Hee. (2002). Workflow Management: Models, Methods, and Systems. Massachusetts. USA: The MIT press

Chapman, James, Mark Glancy and Sue Harper (Edt). (2007). The New Film History: Sources, Methods, Approaches. New York: Palgrave Macmillan

Charon, Joel M. (1979). Symbolic Interactionism. United State of America: Prentice Hall Inc

Dyna Herlina S. Dkk. (2015). Pemetaan Pembuat Film Yogyakarta. Yogyakarta: Dinas Kebudayaan Daerah Istimewa Yogyakarta

Grugulis and Stayonova. (2009). 'I Don't Know Where You Learn Them': skill in television and film. Creative Labour, Working in the Creative Industries (McKinlay,A. and Smith,C., Edt.). New York: Palgrave Mcmillan

John Thornton C. (2008). Production Culture Industrial Reflexivity and Critical Practice in Film and Television. USA: Duke University Press

Jones, M.L. (2005). 'Light... Action... and Grounded Teory': Developing an understanding for management of film production. Rizome, 1(1), 143-153.

Maltby, Richard. (2011). New Cinema Histories. Exploration in New Cinema Histories (Richard Maltby, Daniel Biltereyst, and Philippe Meers. Edt). United Kingdom: Blackwell Publishing Ltd.

Hasibuan, Melayu. (2014). Organisasi dan Motivasi: Dasar Meningkatkan Produktifitas. Jakarta: Bumi Aksara

Rea, Peter W and Irving, David K. (2010). Producing and Directing the Short Film and Video. UK: Elsevier.

Imanda, Tito. (2018). Biar Dhanyang yang Bicara: Film Spiritual dan Pesan Substansial dalam Kolaborasi Produksi Film Tetangga. Komunikator, 10(2), 75-88. 


\section{Veeger, KJ. (1993). Realitas Sosial, Refleksi Filsafat Sosial Atas Hubungan Individu-Masyarakat Dalam Cakrawala Sosiologi. Jakarta: Gramedia.}

